\title{
Ecoviles a Espanya: buscant una transformació social emancipadora?
}

\author{
Luis del Romero Renau \\ Universitat de València. Departament de Geografia \\ luis.romero@uv.es
}

\author{
Rebut: febrer de 2018 \\ Acceptat: octubre de 2018 \\ Publicat: juliol de 2019
}

\section{Resum}

Segons dades de la Global Ecovillage Network (2018), l'Estat espanyol és actualment el segon país més important del món, després dels Estats Units, en nombre d'ecoviles, la xifra de les quals no ha cessat de créixer al llarg dels darrers anys. Seguint la teoria d'Erik Olin Wright sobre transformacions socials emancipadores, tractarem la qüestió de si aquest boom representa una mostra d'una transformació social incipient i d'un canvi cultural que està experimentant el medi rural. Aquest treball es divideix en cinc seccions principals. La primera introdueix el problema, per abordar tot plegat la metodologia realitzada per a l'estudi de 29 ecoviles a Espanya utilitzant sis variables sobre interessos materials i ideologia (Wright, 2010). Les darreres seccions exploren, després d'una concisa discussió conceptual, alguns resultats sobre l'anàlisi realitzada i sobre les pràctiques de reproducció social que han tingut lloc entre ecoviles, dividint-la entre estratègies convencionals i intersticials.

Paraules clau: ecoviles; Espanya; transformació social; espais rurals

\section{Resumen. Ecoaldeas en España: ¿buscando una transformación social emancipadora?}

Según datos de la Global Ecovillage Network (2018), España es actualmente el segundo país más importante del mundo, después de Estados Unidos, en número de ecoaldeas, cuya cantidad no ha cesado de crecer en los últimos años. Siguiendo la teoría de Erik Olin Wright sobre transformaciones sociales emancipadoras, la cuestión que trataremos aquí es si este boom de ecoaldeas es una muestra de una incipiente transformación social y de un cambio cultural que está experimentando el medio rural. Este trabajo se divide en cinco secciones principales. La primera introduce el problema, para abordar inmediatamente la metodología realizada para el estudio de 29 ecoaldeas en España utilizando seis variables sobre intereses materiales e ideología (Wright, 2010). Las últimas secciones exploran, tras una concisa discusión conceptual, algunos resultados sobre el análisis llevado a cabo y sobre las prácticas de reproducción social realizadas entre ecoaldeas, dividiéndola entre estrategias convencionales e intersticiales.

Palabras clave: ecoaldeas; España; transformación social; espacios rurales 
Résumé. Écovillages en Espagne : à la recherche d'une transformation sociale émancipante?

Le nombre d'écovillages existant en Espagne n'a cessé de croître ces dernières années. L'Espagne est actuellement le deuxième pays le plus important au monde, après les ÉtatsUnis, en nombre d'écovillages, selon les données du Global Ecovillage Network (2018). L'objectif de ce travail est d'analyser si ce boom d'écovillages en Espagne est un exemple de transformation sociale émergente et de changement culturel dans les territoires ruraux, selon la théorie d'Erik Olin Wright sur les transformations sociales émancipatrices. Ce travail est divisé en cinq sections principales. La première introduit le problème, en deuxième lieu la méthodologie appliquée à l'étude de 29 écovillages en Espagne, en utilisant six variables concernant les intérêts matériels et l'idéologie (Wright, 2010). Après une discussion conceptuelle concise, les dernières sections explorent, quelques résultats sur l'analyse réalisée et sur les pratiques de reproduction sociale dans les écovillages, en les classifiant en stratégies conventionnelles et stratégies interstitielles.

Mots-clés: écovillages; Espagne; transformation sociale; espaces ruraux

\section{Abstract. Ecovillages in Spain: Looking for an emancipating social transformation?}

The number of ecovillages in Spain has not ceased to grow in recent years. Spain is currently the second country in the world in number of ecovillages after the United States, according to data from the Global Ecovillage Network (2018). Framed in the theory of Erik Olin Wright on emancipating social transformations, the question addressed here is whether this boom in ecovillages in Spain is an example of an incipient social transformation and cultural change of the rural environment. This work is divided into five main sections. The first introduces the problem, followed by the methodology for the study of 29 ecovillages in Spain using six variables on material interests and ideology (Wright, 2010). After a concise conceptual discussion, the last sections explore some results of the analysis and the practices of social reproduction between ecovillages, which are divided between conventional and interstitial strategies.

Keywords: ecovillages; Spain; social transformation; rural areas

\section{Sumari}

\section{Introducció i objectius \\ 2. Antecedents i metodologia}

3. Marc teòric: ecoviles i moviment neorural a Espanya

4. Resultats: ideologia i interessos materials als projectes d'ecovila
5. Discussió: buscant una transformació social?

6. Reflexions finals

Referències bibliogràfiques

Annex 


\section{Introducció i objectius}

Quan pensem en estils de vida alternatius al medi rural, especialment en pràctiques comunitàries crítiques amb la societat capitalista, les ecoviles són sovint un dels primers exemples clars que se'ns presenten (Woods, 2004). En els últims anys, les ecoviles han rebut un renovat interès acadèmic com a objecte d'estudi de formes de vida radicalment oposades a les comunitats consumistes, materialistes i individualistes, que són el cànon de la societat capitalista. Hi ha almenys tres enfocaments diferents que, al llarg dels últims anys, han abordat l'estudi sobre ecoviles com a pràctiques radicals o alternatives. En primer lloc, el moviment de decreixement (Latouche, 2007; D’Alisa et al., 2015) preconitza un qüestionament seriós de les dinàmiques de creixement i la transició cap a societats més justes i equitatives des del punt de vista social i mediambiental. Enfront del consumisme extrem que caracteritza la societat actual, proposen simplicitat voluntària (Latouche, 2007), i en aquest sentit les ecoviles se'n consideren un model. En segon lloc, l'ecovila constitueix un punt d'interès per als autors que reclamen els béns comunals com un conjunt de pràctiques que històricament han caracteritzat moltes zones rurals i que val la pena que sigui rescatat com a possible opció al capitalisme. El paradigma comunal ha estat defensat com una bona alternativa per a la gestió dels recursos naturals, més enllà dels models tradicionals de gestió pública i privada (Ostrom, 1990) $i$, en un sentit més ampli, per a la producció i la reproducció social, des de l'habitatge fins a la família, l'educació o la salut (Menzies, 2014; Laval i Dardot, 2015; Algarra, 2015; Pickerill, 2016) ${ }^{1}$. En aquest sentit, l'ecovila com a construcció d'un projecte emancipador que cobreix tots els aspectes essencials de la vida, des de l'hàbitat fins al menjar, passant per les relacions socials, el treball, l'oci, etc., és un excel.lent camp d'estudi per analitzar els obstacles i els reptes que comporta l'adopció d'un estil de vida alternatiu. Finalment, i des d'una perspectiva ben distinta, les ecoviles sovint s'interpreten com a exemples interessants del nou paradigma i fins i tot del model de negoci batejat com a economia colllaborativa, especialment pel que respecta als patrons de consum (Hong i Vicdan, 2016) o a la seva innovació social (Avelino et al., 2015), que busquen explotar econòmicament «l'idil.li pels espais rurals» (Bell, 2006).

En el cas de l'Estat espanyol, durant més d'una dècada i coincidint amb l'inici de la gran recessió, han aparegut desenes de projectes alternatius de comunitats intencionals, generalment en zones rurals. En termes generals, l'expulsió de milers de persones del mercat laboral per la crisi, d'una banda, a més de la impossibilitat d'accedir al mercat de l'habitatge, de l'altra, juntament amb una geografia rural particular, on els pobles abandonats o amb pocs veïns abunden en àrees muntanyoses i del nord peninsular, són alguns factors que expliquen aquest boom de les ecoviles, dels pobles de "transició", de les coo-

1. Per l'estudi de la importància històrica dels béns comunals a Catalunya, des d'una perspectiva crítica i de reivindicació de les lògiques de cooperació social, suport mutual i reprocitat entre iguals al llarg de la historia catalana, és molt recomanable llegir el llibre de David Algarra (2015). 
peratives d'habitatge sostenible i de moltes altres experiències radicals al medi camperol (Ruiz, 2008; Carretero, 2013). Moltes persones, especialment el jovent, se senten descontentes amb els models dominants de vida urbana basats en el consumisme, la hipermobilitat, la hiperconnexió digital i l'endeutament com a forma d'accés quasi únic a l'habitatge i a les necessitats bàsiques. Per tant, busquen formes de vida alternatives més en contacte amb la natura, amb un component més comunitari i menys consumista i estressant. En aquest sentit, les ecoviles són considerades històricament un dels projectes de vida alternativa més atractius. No obstant això, una pregunta clau que cal abordar és com «d'alternatiu» és avui en dia l'ample i divers ventall d'experiències neorurals en ecoviles a Espanya. L'objectiu d'aquest article és, per tant, avaluar, mitjançant les teories de transformació social emancipadora de Wright (Wright, 2010), si l'actual panorama d'ecoviles existent a l'Estat espanyol pot ser considerat un exemple de pràctica social emancipadora al medi rural ibèric segons la terminologia de Wright, a partir de l'anàlisi de quatre variables relacionades amb la vida diària d'un determinat conjunt d'ecoviles actualment actives, com s'explicarà a l'apartat següent. La hipòtesi que caldria verificar seria, per tant, si les ecoviles com a projecte de vida alternatiu i crític amb el sistema capitalista en molts casos seria un bon exemple de pràctica social emancipadora, seguint les teories de Wright sobre utopies sociopolítiques.

Wright (2010) desenvolupa una interessant teoria de transformació i emancipació social, en la qual es proposa que són tres les utopies diferents que s'han desenvolupat al llarg del darrer segle: transformacions rupturals, intersticials i simbiòtiques. Les transformacions rupturals estan associades amb tradicions polítiques revolucionàries socialistes o comunistes, amb l'objectiu primordial d'enfrontar-se a la burgesia i d'atacar l'estat capitalista. Les transformacions intersticials i simbiòtiques proposen en canvi una trajectòria gradual de modificació, amb una ampliació progressiva dels espais d'apoderament social, però les estratègies intersticials superen àmpliament l'estat nació en la consecució d'aquest objectiu, mentre que les estratègies simbiòtiques intenten utilitzarlo sistemàticament per avançar en el procés d'emancipació social (Wright, 2010: 228). En aquest sentit, les estratègies intersticials estan més relacionades amb la ideologia anarquista; i la metamorfosi simbiòtica, amb tradicions polítiques socialdemòcrates. Sens dubte, l'aparició i la consolidació del moviment d'ecoviles s'insereix històricament en les estratègies intersticials, que, en comptes d'oposar-se frontalment a l'estat capitalista, construeixen alternatives al sistema polític i econòmic hegemònic. De fet, el propi autor proposa el moviment hippy com l'exemple més clar d'estratègies intersticials dins d'un estat capitalista.

La teoria de transformació social de Wright proposa quatre clústers de mecanismes a través dels quals institucions de diversos tipus influeixen en les accions de les persones, tant de manera individual com col-lectiva: coerció, normes institucionals, ideologia i interessos materials. Aquests clústers constitueixen mecanismes de reproducció social capitalista, en la mesura en què, primerament, obstaculitzen accions individuals i col-lectives que amenacen 
les estructures capitalistes de poder i privilegi i, en segon lloc, prenen decisions tot combinant aquests mecanismes, per tal de contribuir positivament a estabilitzar aquestes estructures socials, principalment a través del foment de diferents formes de reproducció passiva del sistema capitalista (Wright, 2010: 195). Analitzar el moviment d'ecoviles a través de la teoria de Wright requeriria qüestionar com desafien en les seves pràctiques quotidianes aquest clúster de mecanismes imposats per l'Estat capitalista i quines estratègies intersticials generen per afrontar la coerció i les normes institucionals de l'Estat, així com per satisfer els seus interessos materials, amb un enfocament ideològic alternatiu més enllà de la lògica del mercat. Aquesta anàlisi és massa àmplia per al propòsit d'aquest treball d'investigació, de manera que només se centrarà en dos dels mecanismes de reproducció social proposats per Wright (ideologia $\mathrm{i}$ interessos materials), deixant els altres dos per a futures contribucions.

\section{Antecedents i metodologia}

El punt de partida d'aquest treball va ser un seminari organitzat el desembre de $2016^{2}$ a la Universitat Politècnica de València, amb la participació de membres de la Global Ecovillage Network i de l'ecovila de Sieben Linden, a Alemanya, un dels projectes d'aquest tipus més consolidats i amb més trajectòria històrica del país. Els fonaments teòrics del treball es basen en la teoria d'emancipació social de Wright (2010). Per avaluar si els projectes d'ecovila actualment actius a l'Estat espanyol s'ajusten al que Wright denomina «estratègies de transformació social intersticial» (Wright, 2010), es va dur a terme una metodologia de tres passos. El concepte operatiu d'ecovila emprat en aquest treball surt dels textos de Bang (2005, citat per Kasper, 2008): «un assentament a escala humana que pretén ser plenament funcional (producció d'aliments, fabricació de béns bàsics, activitats d'oci, oportunitats socials i comerç), amb l'objectiu d'integrar de manera harmoniosa les activitats humanes en el medi ambient de manera compatible, amb un desenvolupament humà saludable. físic, emocional, mental i espiritual» (Bang, 2005, citat per Kasper, 2008).

En primer lloc, a partir de la base de dades de projectes d'ecovila a Espanya (Global Ecovillage Network, 2018), es van presentar quatre criteris de mostreig a l'esmentat seminari, a fi de tenir una mostra robusta, actualitzada i realista de projectes d'ecoviles:

a) El projecte havia d'estar actiu en el moment de realitzar la investigació (any 2017). Se'n van excloure molts projectes quan es va aplicar aquest criteri, perquè encara estaven en formació o construcció o perquè estaven inactius.

2. El seminari va ser organitzat per acadèmics provinents de diferents projectes d'ecovila, especialment per joves investigadors i estudiants de doctorat. El tema general que s'hi va tractar va ser la investigació transdisciplinària en art, ciència i societat. En podeu trobar més informació a l'adreça següent: <http://dparq.upv.es/sin-categoria/jornada-practica-y-metodos-de-investigacion-transdisciplinaria-entre-arte-y-ciencia-recartografias-e-iniciativas-innovadoras-sostenibles $>$. 
b) Només es van triar comunitats de més d'una família.

c) Se'n van excloure els hotels i les activitats comercials relacionades amb el turisme, tot i que n'hi havia algunes que s'anunciaven com a ecovila, perquè més aviat es tractava d'iniciatives que es podrien emmarcar dins del capitalisme verd.

d) També se'n van excloure comunitats religioses o espirituals tancades en àrees aïllades, com ara centres alternatius o budistes, sense cap altre objectiu que practicar-hi l'espiritualitat i la contemplació.

Després d'aplicar aquests criteris, es van escollir 29 projectes d'ecovila. Aquesta xifra amb prou feines comprèn un $24 \%$ del total de projectes inclosos a la Red Ibérica de Ecoaldeas. Els principals motius d'exclusió en van ser els criteris $a \mathrm{i} c$. D'una banda, hi ha molts programes inactius o que encara s'estan formant i, de l'altra, n'hi ha molts altres que realment funcionen com a empresa turística dins del paradigma del capitalisme verd.

Es va establir contacte amb cadascuna de les 29 ecoviles mitjançant el correu electrònic per recollir dades primàries sobre com s'enfronten, en la teoria $\mathrm{i}$ en la pràctica, a les necessitats bàsiques diàries (interessos materials $\mathrm{i}$ ideologia). Així mateix, es va analitzar tota la informació disponible a Internet sobre cadascuna de les ecoviles, incloent-hi notícies de mitjans de comunicació, blogs, publicacions en revistes, etc., a fi d'elaborar una base de dades sobre aquest tipus d'agrupacions humanes. Es va triar un total de sis variables que estaven inspirades en les «quatre finestres de sostenibilitat» —ecologia, economia, comunitat i consciència- proposades per Litfin (2014) en un estudi exhaustiu basat en catorze ecoviles de tres continents i que s'adapten a la definició de Wright sobre els mecanismes d'interessos materials i d'ideologia com a eina d'emancipació social: accés a l'aigua, subministrament d'energia, model alimentari, tècniques de construcció, model de propietat i activitats econòmiques.

Les primeres quatre variables es refereixen a necessitats materials que solen formar part de les lògiques del mercat en les democràcies liberals occidentals. Seguint la teoria de Wright, els projectes alternatius que busquen generar la seua pròpia energia i subministrament d'aigua, de materials de construcció o de producció d'aliments fora de la lògica del mercat serien uns exemples excellents de transformació social emancipadora. Les altres dos variables (accés a l'habitatge i activitats econòmiques) fan referència a uns altres aspectes vitals essencials amb un important component ideològic per a un projecte d'ecovila, ja que així mateix solen formar part de lògiques o d'institucions orientades al mercat. Les alternatives quant a accés a l'habitatge i a un treball fora del mercat es consideren pràctiques emancipadores de transformació social i excel.lents exemples d'estratègies intersticials, com ara la masoveria urbana, l'autoconstrucció, els espais comunals o ocupats i les cooperatives d'habitatge. Per contra, les ecoviles amb accés tradicional a la terra i a l'habitatge mitjançant compra o lloguer es consideren pràctiques no intersticials o convencionals. Per tant, a partir de la informació proporcionada per les ecoviles, cadascuna de les sis 
Taula 1. Estratègies convencionals i intersticials per a la reproducció social d'ecoviles

\begin{tabular}{|c|c|c|c|c|c|c|}
\hline & $\begin{array}{l}\text { Subministrament } \\
\text { d'aigua }\end{array}$ & $\begin{array}{l}\text { Subministrament } \\
\text { d'energia }\end{array}$ & $\begin{array}{l}\text { Model } \\
\text { d'alimentació }\end{array}$ & $\begin{array}{l}\text { Materials i tècniques } \\
\text { constructives }\end{array}$ & $\begin{array}{l}\text { Model de } \\
\text { propietat }\end{array}$ & $\begin{array}{l}\text { Activitats } \\
\text { econòmiques }\end{array}$ \\
\hline $\begin{array}{l}\text { Estratègies } \\
\text { convencionals } \\
\text { de reproducció }\end{array}$ & $\begin{array}{l}\text { Accés a xarxa } \\
\text { convencional } \\
\text { d'aigües. }\end{array}$ & $\begin{array}{l}\text { Accés a xarxa } \\
\text { elèctrica conven- } \\
\text { cional. }\end{array}$ & $\begin{array}{l}\text { Compra a superfícies } \\
\text { comercials tradici- } \\
\text { onals. }\end{array}$ & $\begin{array}{l}\text { Tècniques modernes i } \\
\text { materials artificials. }\end{array}$ & Privat o públic. & $\begin{array}{l}\text { Basades en l'oferta } \\
\text { d'allotjament i de } \\
\text { cursos de formació. }\end{array}$ \\
\hline $\begin{array}{l}\text { Estratègies } \\
\text { intersticials }\end{array}$ & Fonts pròpies. & $\begin{array}{l}\text { Autogeneració } \\
\text { amb energies } \\
\text { renovables. }\end{array}$ & $\begin{array}{l}\text { Alt nivell de sobirania } \\
\text { alimentària mitjan- } \\
\text { çant la permacultura, } \\
\text { l'alimentació local } \\
\text { i l'ecològica. }\end{array}$ & $\begin{array}{l}\text { Materials de construcció } \\
\text { locals i naturals, com } \\
\text { també tècniques de } \\
\text { bioconstrucció. }\end{array}$ & $\begin{array}{l}\text { Gestió comunal, } \\
\text { masoveria, } \\
\text { custòdia } \\
\text { del territori, } \\
\text { okupacions. }\end{array}$ & $\begin{array}{l}\text { Neocamperols, volun- } \\
\text { tariat, economia } \\
\text { col·laborativa, a } \\
\text { més de sistemes de } \\
\text { bescanvi i monedes } \\
\text { socials. }\end{array}$ \\
\hline
\end{tabular}

Font: elaboració pròpia adaptat de Wright (2010).

variables es va dividir en dues categories: estratègies convencionals i intersticials per a la reproducció social.

Finalment, com a complement d'aquesta recerca, es va realitzar una visita breu a una de les ecoviles més consolidades de l'Estat espanyol, el cas de Matavenero, a Lleó (Fernández, 2013), i es van realitzar cinc entrevistes informals (vegeu l'annex) per contrastar algunes de les anàlisis realitzades i, per tant, abordar adequadament el debat final d'aquesta investigació. Seguint les regles de la comunitat local, no se'n poden incloure fotografies ni entrevistes gravades, de manera que la informació obtinguda durant aquest treball de camp s'ha de considerar simplement un suport secundari. L'anàlisi de la gestió dels interessos concrets (aigua, energia, alimentació i materials de construcció), així com d'aspectes ideològics com ara el model polític, social i econòmic de cada ecovila (tipus de propietat de què es tracta i d'activitats econòmiques que s'hi realitzen), complementat amb les entrevistes informals realitzades, és el material a partir del qual s'aborda la qüestió central d'aquesta investigació, sobre la consideració de les experiències neorurals en ecoviles com a pràctiques radicals.

\section{Marc teòric: ecoviles i moviment neorural a Espanya}

Segons Dawson (2015, citat per Accioly et al., 2017), les ecoviles són enormement heterogènies $\mathrm{i}$ és impossible establir un model que en cobreixi tots els casos. Aquesta heterogeneïtat prové dels seus orígens diversos, com ara els ideals d'autosuficiència; les iniciatives espirituals budistes; els moviments ecologista, pacifista, feminista i d'educació alternativa; els de tornada a la terra als països desenvolupats i de contraurbanització (Woods, 2004), i els de desenvolupament participatiu i d'apropiació tecnològica al Sud Global (Litfin, 2014). La Global Ecovillage Network (2018) defineix el terme ecovila com una comunitat intencional, tradicional o urbana que utilitza processos participatius locals per integrar les dimensions ecològiques, econòmiques, socials i culturals de la sostenibilitat per regenerar entorns socials i naturals. No obstant això, 
aquesta xarxa global remarca l'heterogeneïtat de les pràctiques incloses sota el paraigua del concepte d'ecovila.

Per contra, és més facil trobar una definició més precisa del concepte neorural a la literatura acadèmica. Segons Folch (2011), el moviment neorural es podria definir com un grup de persones que abandonen el seu lloc d'origen, en general la ciutat, per pròpia iniciativa, a fi d'establir-se en un entorn rural i començar un projecte de vida comunitari. Moviments culturals i artístics com ara el Romanticisme, autors de l'estil de Thoreau, iniciatives polítiques com ara el socialisme utòpic de Fourier, Owen o Saint-Simon, i al segle xx la cultura hippy o el Maig del 68, i sobretot el despertar de la consciència ambiental, són els referents ideològics dels moviments neorurals i de projectes d'ecoviles com a forma de contraurbanització per part sobretot de classes mitjanes (Woods, 2004; Resina i Viestenz, 2012; Fernández, 2013: 3; Accioly et al., 2017).

Tanmateix, en la decisió de canviar la forma de vida d'un model capitalista urbà a un altre d'alternatiu, per a alguns autors com ara Hervieu i Léger (1979) hi ha unes altres raons més pràctiques més enllà d'un cert «idil.li» pel món rural (Bell, 2006), principalment la manca d'oportunitats laborals a la ciutat. Hervieu i Léger (1979) sostenen que en lloc de tornar al camp, cal parlar del camp com a recurs per a l'atur, la crisi, la contaminació i la burocratització de la vida social, i, dins d'aquest, les ecoviles desenvoluparien un paper de "refugi social» contra la crisi. En qualsevol cas, es tracta d'un fenomen consolidat a tot el món després de diverses fases, l'última de les quals correspon a la crisi financera internacional de 2007. El moviment neorural avui està ben assentat en molts territoris camperols, la qual cosa comporta l'aparició d'una nova territorialitat, una concepció original de les relacions entre els individus i el seu entorn biosocial i una transició des dels no-llocs en què s'han convertit moltes ciutats estandarditzades fins a espais envoltats de natura i paisatge (Nogué, 1988: 154). De fet, l'entorn rural es converteix, per a molts joves desencantats de la vida urbana, en una mena de talaia des de la qual es pot contemplar el món i en un punt de referència per a construir una identitat diferenciada, tal com va afirmar Relph:

El neorural és, de fet, un immigrant que necessita arrelar-se en el seu nou entorn, que necessita crear «llocs» en un espai que per ell encara no té llocs. El seu projecte de vida en contacte amb la natura i el seu desig d'integrar-se en la societat rural que l'envolta l'ajudaran a aconseguir una «interioritat existencial» amb relativa facilitat. (Relph, 1976, citat per Nogué, 1988. Traducció pròpia)

Ecoviles i neorurals són dos conceptes estretament lligats però diferenciats, ja que ni tots els neorurals habiten en ecoviles ni totes les ecoviles tenen només neorurals entre els seus habitants. No obstant això, hi ha un buit important de literatura sobre l'anàlisi de les ecoviles des de la perspectiva neorural, almenys en referència al cas d'Espanya, tot i que avui és un tema crucial per entendre les àrees rurals de molts territoris ibèrics. Actualment, segons dades de la Global Ecovillage Network (2018), la quantitat de projectes d'ecoviles és superior a 
Figura 1. Nombre d'ecoviles a diferents països

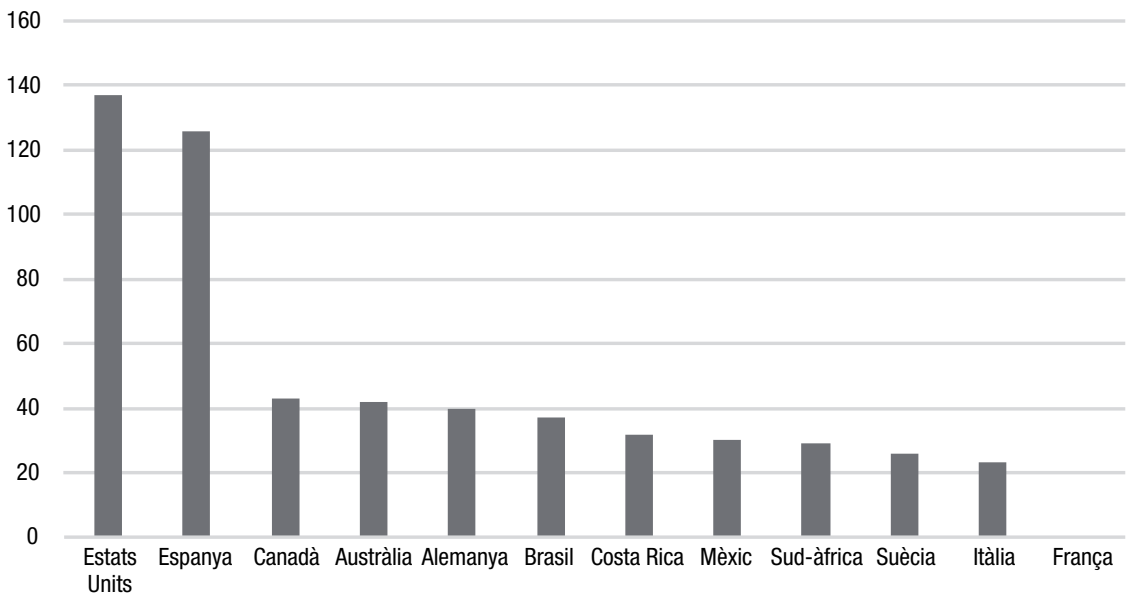

Font: elaboració pròpia a partir de dades de GEN (2018).

1.000 en un total de 110 països. Espanya ocupa ni més ni menys que el segon lloc del món en nombre de projectes, només superat pels Estats Units, una nació molt més extensa i poblada que qualsevol país europeu.

L'estudi del fenomen neorural a Espanya s'inscriu dins dels corrents d'estudi sobre migracions de la ciutat al camp, un tema clàssic en demografia però encara amb poca producció sobre el cas espanyol (Camarero, 1993; Solana, 2008). D'una banda, Espanya és un estat amb 8.116 municipis, en un $60 \%$ dels quals (4.929) hi ha menys de 1.000 habitants i 1.238 tenen menys de 100 habitants (Instituto Nacional de Estadística, 2018). L'èxode rural i la crisi han estat històricament tan profundes que a gairebé totes les comunitats autònomes, però especialment al nord (Galícia, Astúries, Castella i Lleó i Aragó), és normal trobar-hi pobles abandonats i milers de cases i granges buides susceptibles de ser ocupades o habitades de nou per neorurals (Del Romero, 2018). A més, molts d'aquests llocs solen tenir terres agrícoles, pastures i boscos de bona qualitat. A part d'això, el clima mediterrani predominant hi facilita significativament el desenvolupament de projectes vinculats a l'agricultura o a la ramaderia. En general, el medi camperol és accessible des de les regions urbanes centrals de les quals provenen gran part dels neorurals, com ara Madrid i Barcelona, o altres ciutats europees, com ara París, Londres, Frankfurt o Milà. Aquesta condició geogràfica ha conduït, segons alguns autors, a un procés de «naturbanització» en algunes zones rurals (Prados, 2009; Pallarés-Blanch et al., 2014), que es defineix com la recerca de nous espais de vida en àrees naturals d'alta qualitat ambiental i estètica, sovint per part de comunitats neorurals, a fi de crear comunitats que impulsin activitats agrícoles tradicionals i altres iniciatives basades en el consum de la natura (Prados, 2009). 
Més enllà dels factors geogràfics o econòmics, la crítica a les formes de vida urbanes hiperconnectades i esgotadores és un important factor camperol d'atracció mitjançant la construcció d'un «idil.li rural» (Nogué, 1988; Mingay, 1989; Cloke, 2003; Bell, 2006; Folch, 2008; Guirado, 2012). Guirado (2012) analitza les motivacions de neorurals procedents de diferents països europeus per haver canviat el món urbà per petites comunitats intencionals, generalment situades en zones aïllades de la muntanya. Cáceres-Feria i Ruiz (2017) amplien aquesta anàlisi centrant-se en l'impacte social, cultural i econòmic dels neorurals estrangers arribats des de les ciutats d'Europa occidental fins a les zones camperoles espanyoles en crisi. Contràriament, Cortés-Vázquez (2014) estudia els conflictes de relacions de poder entre neorurals i altres grups socials a través de l'anàlisi de pràctiques quotidianes sobre el dret a l'ús i l'accés als recursos locals, conflicte que Guirado (2012) centra en el punt de vista de les tensions entre la població autòctona i la nouvinguda. Tots aquests autors coincideixen a afirmar que un factor decisiu va ser la crisi financera que va afectar principalment Espanya entre 2007 i 2014, període en el qual hi va haver una important incorporació de joves neorurals a distintes àrees camperoles, amb ecoviles o sense (Hilmi i Burbi, 2016; Fanjul, 2015).

En l'anàlisi sobre el potencial contrahegemònic d'algunes comunitats rurals, incloent ací els projectes d'ecovila, algunes contribucions se centren en el desenvolupament d'alternatives per cobrir les necessitats bàsiques fora de la lògica del mercat (Accioly et al., 2017; Wilbur, 2013; Litfin, 2014, Halfacree, 2007). A Espanya, algunes obres inclouen l'estudi sobre economies alternatives, neocamperols i moviments de sobirania alimentària (Calvário i Kallis, 2017; Calvário, 2017), estratègies alternatives d'habitatge centrades en l'okupació rural (Cattaneo i Gavaldá, 2010) i literatura més àmplia sobre bioconstrucció i construcció d'habitatges ecològics (Pickerill, 2016) i ecoviles com a estils de vida alternatius (Folch, 2008; Ruiz, 2008; Marconi, 2015). Aquestes contribucions tenen en comú l'estudi d'experiències d'ecoviles situades a Espanya i poblades per neorurals procedents d'entorns urbans, descontents o crítics amb la lògica capitalista.

\section{Resultats: ideologia $\mathrm{i}$ interessos materials als projectes d'ecovila}

Les dues figures següents mostren els resultats de la base de dades elaborada per abordar la qüestió de si els moviments neorurals que desenvolupen projectes d'ecovila es poden caracteritzar com a exemples de transformació social emancipadora, tot i encaixant en el concepte d'estratègia intersticial de Wright (2010). La figura 2 mostra en un mapa la ubicació dels 29 projectes d'ecovila analitzats amb la seva població aproximada. La figura 3 il.lustra com aquestes ecoviles estan afrontant les seues necessitats bàsiques, dividides entre ideologia i interessos materials, d'acord amb la teoria de la transformació social de Wright, tot seguint la metodologia exposada a la secció 2 . Aquesta figura mostra quantes estratègies intersticials s'han identificat a cada ecovila. A més a més, a l'annex s'hi pot trobar la taula que recull els resultats detallats per a cadascuna de les 29 ecoviles estudiades. 
Figura 2. Ecoviles a Espanya amb la seva població aproximada

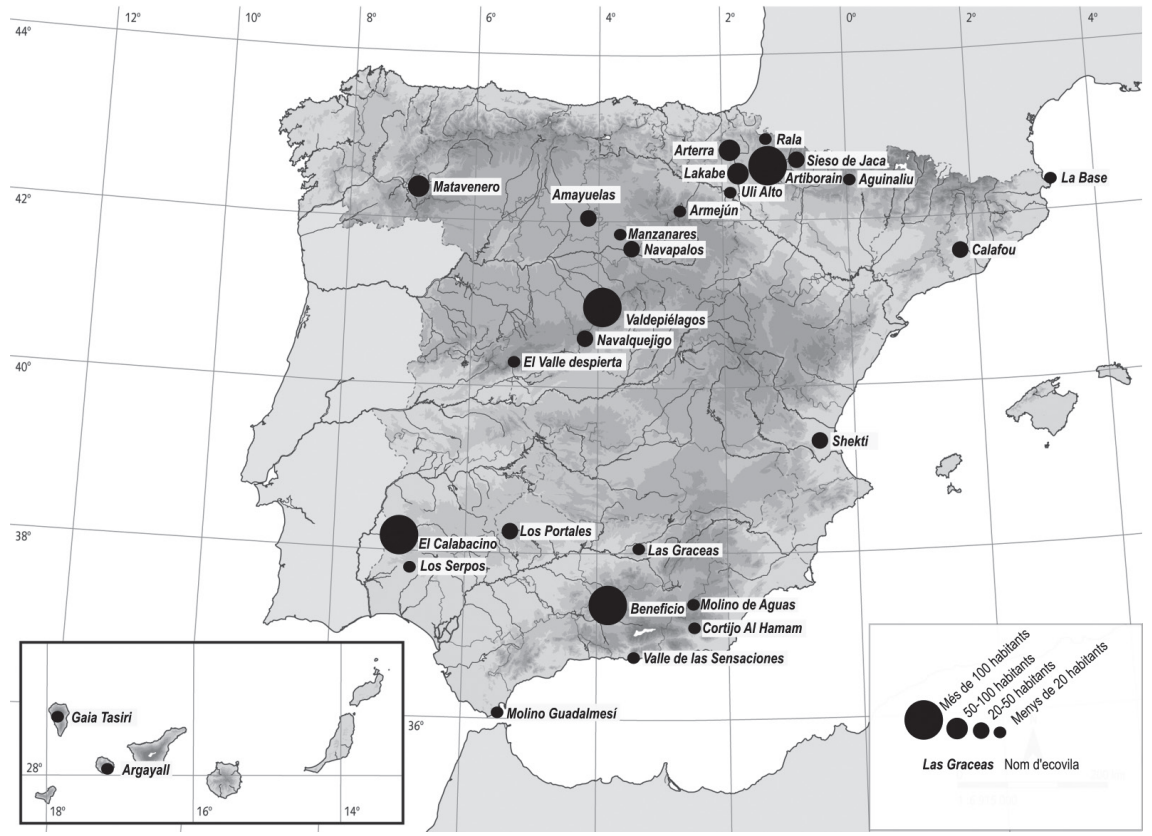

Font: elaboració pròpia a partir de bases de dades sobre ecoviles.

Tal com es pot observar a la figura 2, totes les ecoviles estudiades es troben en un entorn rural, gairebé sempre en zones de muntanya i lluny de les principals ciutats i zones turístiques, excepte potser en els dos casos de les Illes Canàries. Un $44 \%$ són pobles abandonats o parcialment rehabilitats, un $24 \%$ són explotacions agropecuàries i un $16 \%$ són nous assentaments. Per tant, la majoria dels projectes es desenvolupen en àrees poblades antigament. Tal com hem explicat a la secció anterior, les condicions geogràfiques també hi tenen un paper destacat. Nou ecoviles, un 31\% del total, es troben a Andalusia, amb un clima assolellat, hiverns suaus i unes condicions ambientals adequades per a l'agricultura. Uns altres territoris amb condicions climàtiques mediterrànies o subtropicals semblants podrien ser Catalunya, València o Canàries, on hi ha conjuntament cinc ecoviles més, de manera que gairebé el $50 \%$ de les ecoviles es localitzen a territoris amb clima mediterrani sec o subtropical. L'altre $50 \%$ es concentra a les zones muntanyoses continentals, que contenen una gran oferta de sòl disponible i d'habitatges abandonats, amb una bona accessibilitat relativa des de les ciutats principals, fonamentalment Madrid i Barcelona. De fet, deu ecoviles (un 34,4\%) estan ubicades a menys de tres hores amb cotxe d'aquestes àrees urbanes, i la gran majoria són accessibles des d'altres àrees metropolitanes (València, Sevilla, Bilbao o Saragossa) en menys de dues hores. 
Figura 3. Ideologia i interessos materials a les ecoviles. Ecoviles amb estratègies intersticials a partir de la taula 1

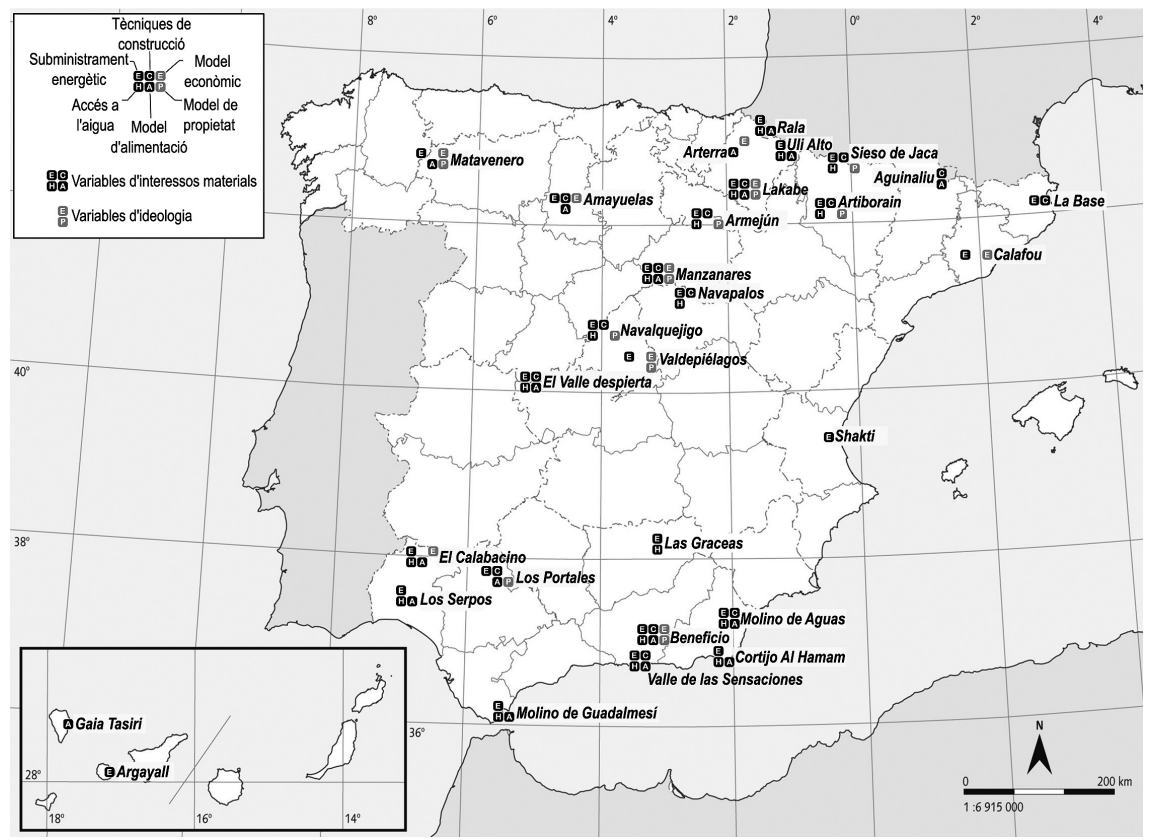

Font: elaboració pròpia a partir de bases de dades sobre ecoviles.

Tanmateix, els resultats de l'anàlisi dels interessos materials i ideològics mostren una certa heterogeneïtat. Hi ha un consens generalitzat per a les dues primeres variables: l'accés a l'aigua i l'energia. Gairebé el $60 \%$ de les ecoviles té el seu propi cicle d'aigua i el $62 \%$ se subministra amb energies renovables. Moltes ecoviles destaquen la importància de l'autogestió de l'energia i l'aigua en els seus discursos i descripcions de projectes, i en molts casos es posa en pràctica com un element essencial de la iniciativa. Aquest consens inclou també la sobirania alimentària. La gran majoria de les ecoviles afirmen que cerquen alternatives a les xarxes convencionals de distribució d'aliments i que aposten per l'autoproducció lligada a la permacultura, a l'agroecologia o a dietes veganes i vegetarianes. Gairebé el 60\% de les ecoviles tenen un alt grau d'autoproducció alimentària, un excel-lent exemple d'estratègia intersticial per a afrontar un dels aspectes més criticats de la reproducció social convencional sota el capitalisme: l'alimentació, lligada a la nutrició i la salut. No obstant això, encara que a la majoria de les ecoviles s'hi realitzen activitats agrícoles i ramaderes, a penes un terç del total afirma que són productores un $100 \%$ ecològiques. En aquest sentit, els projectes d'ecovila no sempre estan relacionats amb el conreu ecològic, ja que n'hi ha molts que bàsicament es dediquen a activitats educatives de tot tipus, des de cursos de bioconstrucció fins a ioga 
o formació en permacultura, i es continuen proveint d'aliments a cadenes comercials convencionals.

El consens sobre les altres tres variables no és tan facil de trobar. El 55\% de les ecoviles afirma que l'assentament va ser edificat amb materials de construcció naturals, locals i ecològics, seguint criteris de bioconstrucció; el 34,7\% segueix un model alternatiu o radical per a l'accés a la terra, com ara l'okupació, les cooperatives d'habitatges o la propietat comunal, i menys del $28 \%$ presenta models econòmics o monetaris alternatius, com ara monedes socials, sistemes de bescanvi, promoció d'intercanvis locals, activitats agrícoles no capitalistes o sistemes de producció comunals. Començant per l'última variable, potser aquesta és la més complexa d'analitzar, ja que implica ocupació, ingressos, relacions amb la població local, diners i necessitats bàsiques, com ara l'educació o la salut, que actualment no es desenvolupen en projectes petits d'ecovila. Un exemple d'aquesta complexitat és el cas de Matavenero. Molts dels seus membres treballen fora de la comunitat, mentre que uns altres ho fan per a la pròpia comunitat i reben un salari a canvi:

Si vens sense res, pots guanyar-te la vida ajudant els altres (i aquesta és una de les raons per les quals algunes persones fan cap a l'ecovila), però si no tens res per oferir, necessites la teua pròpia economia per sobreviure. (Traducció pròpia)

\section{Entrevista 1}

A diferència de les primeres ecoviles que van sorgir als anys seixanta i que estaven dedicades principalment a l'agricultura, a la ramaderia o a l'artesania (Nogué, 1988), ara hi ha una diversitat més elevada d'activitats. Encara trobem moltes ecoviles que combinen un perfil d'agricultor i artesà, però actualment hi veiem un segon model, que és el de l'ecovila com a centre de formació i d'estada temporal. Finalment, hi ha una gran quantitat d'ecoviles, gairebé un terç del total, que combinen una àmplia varietat d'iniciatives, des de la producció artesana fins a una variada oferta formativa, activitats forestals o treball en altres pobles. Per tant, és difícil reduir aquesta variable a una distribució binària entre pràctiques econòmiques convencionals o radicals. Després de l'estudi d'aquesta variable, també és interessant observar la complexitat de la relació entre neorurals i població local. Només set ecoviles mantenen relacions econòmiques i socials importants amb la comunitat local, i únicament en un cas, Valdepiélagos a Madrid, l'ecovila és en si mateixa una part del poble, mentre que la resta es troba en zones abandonades o aillades.

Una altra qüestió important és l'accés a una propietat. La gran majoria de les comunitats neorurals decideixen comprar terrenys o llogar-ne, encara que les inversions requerides siguin considerables ${ }^{3}$. Paradoxalment, l'entorn

3. Algunes agències immobiliàries s'han especialitzat en la venda de pobles abandonats, amb preus que oscil.len entre 50.000 euros per una masia fins a 4 o 5 milions d'euros per un poble sencer o un castell. Es tracta de propietats que en general necessiten inversions molt costoses per ser rehabilitades. Vegeu: <www.aldeasabandonadas.com>. 
rural espanyol és ric en tradicions de gestió comunitària i cooperatives. Moltes terres, boscos i pastures, així com molins, forns, escoles o cases avui abandonades van ser construïdes i mantingudes per una comunitat local i no per una administració pública i, per tant, no eren propietats privades ni públiques (Del Romero, 2018). Molt poques ecoviles, específicament només tres, han incorporat en el seu projecte la recuperació d'aquests béns comunals amb la connivència o el coneixement de la població local. La resta sembla que prefereix un model basat en la propietat privada, que no està associat amb discursos anarquistes radicals que proposen uns altres models. Això podria ser un exemple del que Accioly et al. (2017) denomina "caràcter elitista de les ecoviles dels països rics", amb membres que provenen de classes mitjanes o altes i que posseeixen un poder adquisitiu elevat (Ergas, 2010, citat per Accioly et al., 2017).

Finalment, les ecoviles que afirmen que segueixen els criteris de bioconstrucció, utilitzant elements i tècniques locals i sostenibles, només inclouen el $55 \%$ del total. La majoria de casos reconeix que fa servir materials convencionals, com ara el formigó, el plàstic o uns altres recursos industrials moderns que no encaixen amb el tòpic d'una ecovila com la cabanya de Thoreau a Walden.

\section{Discussió: buscant una transformació social?}

D'una banda, les zones rurals espanyoles sembla que són un fertil laboratori social per als projectes d'ecovila. D'altra banda, malgrat el boom que ha experimentat el neoruralisme a Espanya a causa de la crisi econòmica, la població permanent que integra totes les ecoviles que formen part de la Red Ibérica de Ecoaldeas se situa al voltant de 10.000 persones en un immens entorn rural (menys de 2.000 a les ecoviles estudiades). El nombre de projectes és considerable, però en general la població que hi està implicada és simbòlica, encara que en alguns casos, com Artiborain als Pirineus o Valdepiélagos a Madrid, es tracta d'una quantitat de població significativa a nivell local.

Considerant les variables estudiades, només dos casos, Beneficio a Las Alpujarras (Granada) i Lakabe a Navarra, tenen estratègies intersticials clares vinculades a les sis variables estudiades, des del dret lliure a establir-se en el cas de Beneficio fins a un alt grau d'autonomia en les necessitats bàsiques en el cas de Lakabe. Aquests dos projectes tenen en comú una llarga durada i haver sigut establerts als anys vuitanta per diferents col-lectius anarquistes i hippies. Per contra, algunes ecoviles recents sembla que desenvolupen un projecte en el qual les estratègies intersticials, o fins i tot els discursos radicals, són difícils de trobar. En alguns casos, per exemple, el fet de voler ser autosuficients en el cicle de l'aigua o en la generació d'energia sembla que es tracta més d'una decisió pràctica que no pas política.

La gran paradoxa del moviment neorural a les ecoviles és que la gran majoria d'habitants són urbanites que provenen precisament d'aquest món indesitjat i sense habilitats professionals per treballar en l'agricultura, la ramaderia o l'artesania. En aquest sentit, en molts casos el reciclatge professional és un repte important per a molts dels nouvinguts, però una quantitat important de 
persones no s'adapten al nou entorn. A això cal sumar-hi el context particular viscut a Espanya, especialment durant els anys 2011 a 2014, tal com s'ha explicat en apartats anteriors, la qual cosa va empènyer milers de famílies a buscar una sortida a la crisi mitjançant aquests projectes (Carretero, 2013). Algunes organitzacions mediadores, com ara Abraza la Tierra, han rebut durant dècades desenes de sol.licituds d'informació sobre àrees rurals. Segons aquesta associació, la causa principal d'aquestes migracions va ser més la desesperació per una situació econòmica molt precària que no pas la voluntat de canviar (Larrañeta, 2016). En aquest sentit, algunes ecoviles van sorgir o van actuar més com a refugi social enfront de la crisi que no pas com a iniciativa d'apoderament personal, la qual cosa confirmaria les tesis d'Hervieu i Léger (1979) exposades abans. Algunes ecoviles van ser formades o reforçades per persones literalment excloses del mercat laboral urbà, en comptes de per unes altres que desitjaven un canvi voluntari cap a un model de vida en comunitat lligat a estratègies intersticials.

Per contra, alguns altres casos analitzats aquí són projectes d'ecovila sorgits abans de la crisi i que han recorregut una llarga trajectòria. A part dels casos de Beneficio i Lakabe, hi ha alguns exemples com ara Valdepiélagos a Madrid, Matavenero a León, Arterra a Navarra o Artiborain als Pirineus, amb dècades d'història, una comunitat estable i un discurs clar relacionat amb la necessitat de crear una alternativa al capitalisme mitjançant el desenvolupament de pràctiques emancipadores socials. No obstant això, en alguns casos s'ha imposat el pragmatisme a qualsevol objectiu polític de construir «alternatives socials». L'objectiu de crear comunitats més sostenibles és, sens dubte, la seva aspiració principal, però la majoria renuncien a qüestions estructurals com ara la propietat de la terra, les relacions exteriors o econòmiques o el sistema educatiu. Particularment en la qüestió de la propietat, tot i que hi ha una crítica implícita al concepte de propietat privada en moltes ecoviles, atesa la inseguretat jurídica de l'okupació, molts projectes comencen amb la compra d'una parcel.la o d'una casa. Aquesta és la diferència principal entre el moviment neorural i el moviment okupa, que està estretament relacionat amb idees anarquistes i més present a les ciutats.

És potser en el model econòmic i social on hi ha més heterogeneïtat d'ecoviles. Alguns d'aquests projectes comparteixen models inspirats en l'ecologia política, amb un fort èmfasi en la igualtat i l'equitat entre els seus membres, el respecte vers totes les orientacions sexuals i el món animal, però el seu model financer difereix poc de la lògica empresarial de qualsevol organització econòmica. De vegades, en comptes de l'ecovila, alguns projectes sembla que tinguin com a activitat principal (però no única) l'oferta de cursos de meditació o d'artesania a tarifes poc accessibles per a moltes persones ${ }^{4}$, la qual cosa reforça una vegada més la idea de considerar alguns projectes neorurals com a elitistes.

Un altre aspecte crític relacionat amb el model econòmic i social són les connexions personals externes en les ecoviles. En molts casos les relacions entre

4. Algunes ecoviles ofereixen cursos d'un dia o dos per 250-300 euros, quan el salari mínim a Espanya per a 2018 és de 24 euros al dia (SEPE, 2018). 
neorurals i veïns són tenses per la manca de comunicació de tot tipus. En alguns altres casos, com a Sieso de Jaca, Navalquejigo o Manzanera ${ }^{5}$, hi va haver conflictes amb la població local, per exemple, com a conseqüència de l'okupació de propietats privades. Encara que alguns neorurals hi viuen des de fa dècades, de vegades continuen sent indesitjats per la població local, que no comprèn la seva filosofia de vida. Un important estudi sobre el moviment neorural a l'Aragó va arribar a aquesta conclusió després d'entrevistar 23 neorurals en diversos pobles, sis dels quals afirmaven que estaven en conflicte amb la població local (Ibargüen et al., 2004: 36-38) Aquest és el cas, per exemple, de Matavenero, un projecte consolidat d'ecovila que, malgrat tot, és poc conegut pels habitants dels pobles del voltant:

La veritat és que s'assemblen a una comuna hippy. Els seus habitants són força curiosos. Solament hi vaig anar una vegada des d'una ruta de senderisme de San Facundo i em vaig aturar al bar a prendre alguna cosa. (Traducció pròpia)

\section{Entrevista 2}

D'altra banda, la desconfiança és mútua, ja que moltes ecoviles s'han convertit en un focus de turisme alternatiu per a forans i de curiositat per als habitants locals. Alguns neorurals solen queixar-se de la seva pèrdua de privacitat, ja que cada dia hi ha veïns i turistes que visiten l'ecovila:

La majoria de les persones que venen aquí ens veuen com si fóssim micos de fira, com una atracció turística. De vegades ens falten al respecte i envaeixen la nostra privacitat. Ets a casa teva i de sobte se t'acosten amb una càmera i et fan fotos sense demanar-te permís, com si fossis un Hippy vulgaris. (Traducció pròpia)

\section{Entrevista 3}

Aquest conflicte s'ha d'estudiar amb més detall en futures contribucions, però és un factor fonamental per explicar les causes del reduït nombre d'ecoviles actives existents a Espanya, així com l'impacte social limitat a les zones rurals, fins i tot per a dubtar si alguns dels projectes busquen algun tipus de transformació social o més aviat simplement l'aïllament social.

Finalment, per comprendre la voluntat pragmàtica de molts d'aquests projectes, cal assenyalar que el paper de l'Estat, tant per part dels governs autonòmics com del central i d'algunes administracions locals, ha sigut desincentivar aquesta forma de vida. La fiscalitat onerosa, la dificultat d'obtenir llicències de construcció o la reacció sovint violenta quan s'estableix una ecovila en terrenys

5. Sieso de Jaca i Navalquejigo són ecoviles consolidades que tanmateix tenen un llarg historial de conflictes legals i socials amb els veïns (vegeu Puebla, 2015, i l'article «Un pueblo abandonado a su suerte», 2017, a la bibliografia). El cas de Manzanares, a Sòria, fins i tot va viure un episodi d'assetjament i d'agressió física a alguns neorurals (Claramunt, 2015). 
públics en són alguns exemples. En alguns casos, el conflicte entre l'Estat i algunes ecoviles arriba fins a l'ocupació policial del lloc. Aquest va ser el cas de Fraguas, però almenys hi va haver tres casos més que van patir problemes similars 6 . Això demostra que l'estratègia de transformació de l'Estat es pot descriure com a ruptural pel que fa al moviment d'ecoviles, que és contínuament assetjat perquè es tracta d'un moviment que pràcticament s'escapa del seu control. Opera aquí el mecanisme de coacció i de normativisme institucional per limitar i desincentivar els projectes d'ecovila. Fins i tot és un xoc o un conflicte cultural en l'àmbit acadèmic, especialment quan els neorurals de segona generació assisteixen a l'educació secundària i hi troben un estil de vida completament diferent:

Em sentia lliure a Matavenero, i quan vaig anar a l'institut no sabia menys que els altres, però no em podia acostumar a tenir tantes regles. Em vaig queixar perquè la gent no em prenia seriosament. Tinc 12 anys $\mathrm{i}$ ja sé què haig de fer i què no... Però hi ha regles per a tot! (Traducció pròpia)

\section{Entrevista 4}

En resum, si bé és cert que la filosofia compartida per gairebé totes les ecoviles s'adapta perfectament a algunes de les estratègies intersticials proposades per Wright (2010), com ara l'autosuficiència energètica o la sobirania alimentària, en la pràctica la majoria de comunitats identificades com a ecoviles a Espanya són molt menys radicals del que es podria esperar: propietat privada, materials de construcció convencionals o activitats econòmiques basades en el turisme rural, l'educació i la formació espiritual per unes tarifes considerables. Heus aquí una de les contradiccions essencials trobades en aquest estudi: la defensa d'alguns mecanismes que podrien relacionar-se amb estratègies intersticials i anticapitalistes, com ara la producció local d'aliments ecològics, l'ús de recursos energètics renovables o les tècniques de bioconstrucció, que sembla que segueixin un narrativa de greenwashing, l'objectiu principal de les quals, però, més que una alternativa d'apoderament social per difondre i defensar, és el desenvolupament d'un negoci turístic o d'educació amb ànim de lucre. A això cal sumar-hi el paper que han tingut algunes ecoviles, que més aviat han representat un refugi social per fer front a l'austeritat que no pas un canvi de vida voluntari per a molts joves desocupats.

6. Fraguas és un llogaret abandonat dins del Parc Natural de Sierra Norte de Guadalajara que va ser ocupat el 2013 per un grup de dotze neorurals que van ser desallotjats per la policia durant la primavera de 2017. Fins i tot n'hi va haver alguns que van ser acusats d'un "delicte greu contra l'ordenació del territori» en una zona molt despoblada que avui pertany al municipi del Monasterio (Guadalajara), on només viuen 16 habitants permanents. La condemna que se'ls ha imputat ha estat de dos anys de presó. Molts altres casos d'ecoviles estudiades pateixen problemes legals diferents amb els governs locals i autonòmics, principalment El Calabacino, Sieso de Jaca o Matavenero, a causa de la prohibició d'ocupar àrees protegides, encara que aquests projectes es desenvolupen en zones prèviament urbanitzades, com ara pobles abandonats i sense valors naturals. 
En canvi, alguns altres casos més vinculats als moviments anarquistes, ecologistes o feministes han demostrat que, malgrat les dificultats tècniques, la coerció per part de l'Estat, les contradiccions internes i altres problemes, és possible desenvolupar projectes de vida alternatius vinculats a estratègies intersticials que cobreixen gairebé totes les necessitats bàsiques. Una minoria de les ecoviles estudiades aquí, al voltant de vuit o nou, incloent Beneficio, Lakabe, Artiborain, Arterra, Matavenero, Manzanares, Calafou o Sieso de Jaca, ha aconseguit oferir un projecte de vida alternatiu gairebé autònom i amb pràctiques interessants per proporcionar necessitats bàsiques més enllà de la lògica del mercat capitalista, que podria ser una inspiració per a uns altres neorurals disposats a contribuir realment a realitzar una transformació social emancipadora.

\section{Reflexions finals}

El moviment neorural dins de les ecoviles a Espanya és un fenomen completament assentat i que sens dubte serà durador en el temps. Amb més de 120 iniciatives, Espanya és un dels països del món amb més experiències d'aquest tipus. No obstant això, aquesta contribució ha intentat mostrar que les ecoviles que encaixen realment amb la concepció social d'un grup de neorurals que intenten iniciar un pla emancipador social són escassos, perquè hi ha una gran varietat de projectes que apareixen sota el paraigua del concepte d'ecovila. En aquest sentit no es pot confirmar la hipòtesi proposada a l'inici d'aquest treball.

En molts casos, els projectes d'ecovila impliquen un canvi psicològic i professional per als seus membres, generalment procedents del món urbà, a més d'una transició conscient a un model de vida més sostenible i fins i tot anticapitalista. Tanmateix, en molts altres casos es desenvolupen projectes d'ecovila gairebé aliens als discursos de transformació social. Seria més precís parlar sobre nous emprenedors o sobre la implantació de noves lògiques empresarials en l'entorn rural totalment emmarcades en el paradigma del capitalisme verd. Després de l'anàlisi realitzada sobre les sis variables vinculades a la ideologia $\mathrm{i}$ als interessos materials, seguint la teoria de Wright, és interessant observar que només hi ha dos casos que sembla que duguin a terme pràctiques alternatives relacionades amb totes les necessitats bàsiques, mentre que n'hi ha sis que només formulen alternatives limitades en alimentació, subministrament d'aigua $i$ energia. En aquest sentit, la mostra analitzada en aquest estudi es podria dividir en dos parts: una minoria de casos radicals i un segon grup de casos mixtos en què es realitzen activitats amb finalitat de lucre, estratègies convencionals per cobrir les necessitats bàsiques i una funció social com a refugi contra la crisi.

En termes conceptuals, l'enfortiment de les estratègies intersticials requeriria, en primer lloc, un debat complex dins de les xarxes d'ecoviles, com ara la Global Ecovillage Network o la Red Ibérica de Ecoaldeas, sobre la dissociació entre ecoviles com a projectes de transformació social i uns altres projectes de capitalisme verd amb ànim de lucre. Des d'un punt de vista pràctic, l'enfortiment de les estratègies intersticials que defensen moltes ecoviles en la seva filosofia 
de vida podria trobar un suport fonamental en la cultura popular rural, ja que moltes d'aquestes cultures són i han estat històricament de resistència contra la unificació modernitzant de l'estat nació espanyol, i fins i tot van mantenir en molts casos comunitats que encaixarien amb els principis de decreixement $\mathrm{o}$ amb estratègies intersticials. La gran majoria de les agricultures tradicionals són intrínsecament ecològiques, el paradigma de la propietat comuna versus la privada va ser molt més present a les societats rurals del que es pensa, i fins i tot els sistemes d'intercanvi econòmic basats en el bescanvi eren comuns fins fa pocs anys. L'estudi i la incorporació de la cultura rural tradicional a les ecoviles modernes podria ser el catalitzador del fenomen de l'ecovila com un model de vida intersticial molt més generalitzat, en un entorn rural que necessita desesperadament iniciatives que contribueixin a revitalitzar-lo amb urgència.

\section{Referències bibliogràfiques}

Accioly, Maria et al. (2017). "The meaning and relevance of ecovillages for the construction of sustainable societal alternatives». Ambiente y Sociedade, 20 (3). São Paulo (juliol-setembre). <http://dx.doi.org/10.1590/1809-4422asoc0083v2032017>

Algarra, David (2015). El comú català. Barcelona: Potlach Editorial.

Avelino, Flor et al. (2015). «Transitions towards new economies?: A transformative social innovation perspective». TRANSIT working paper \#3. Brighton.

Bell, David (2006). «Variations on the rural idyll». A: Cloke et al. (ed.). Handbook of rural studies. Londres: SAGE.

CÁceres-Feria, Rafael i Ruiz, Esteban (2017). «Forasteros residentes y turismo de base local: Reflexiones desde Alájar (Andalucía, España)». Gazeta de Antropología, 33 (1).

CalváRIo, Rita (2017). «Food sovereignty and new peasantries: On re-peasantization and counter-hegemonic contestations in the Basque territory». The Journal of Peasant Studies, 44 (2), 406-420. <https://doi.org/10.1080/03066150.2016.1259219>

Calvário, Rita i Kallis, Giorgios (2017). «Alternative Food Economies and Transformative Politics in Times of Crisis: Insights from the Basque Country and Greece». Antipode, 49 (3), 597-616. $<$ https://doi.org/10.1111/anti.12298>

Camarero, Luis (1993). Del éxodo rural y del éxodo urbano. (Ocaso y renacimiento de los asentamientos rurales en España). Madrid: Ministerio de Agricultura, Pesca y Alimentación.

Carretero, Rodrigo (2013). «La huida al mundo rural para escapar de la crisis: "En la ciudad no teníamos ni para comer"». Huffington Post (10 de març de 2017). Recuperat de <http://www.huffingtonpost.es/2013/03/10/la-huida-al-mundorural-por-la-crisis_n_2817366.html>.

Cattaneo, Claudio i Gavaldá, Marc (2010). «The experience of rurban skuats in Collserola, Barcelona: What kind of degrowth?». Journal of Cleaner Production, 18, 581-589.

Claramunt, Teresa (2015). «Agresión en Manzanares, Soria». Portal libertario OACA (12 de juliol). Recuperat de <http://www.portaloaca.com/opinion/10634-agresion-en-manzanares-soria.html>. 
Cloke, P. (2003). Country visions. Essex: Pearson.

Cortés-VÁzQuez, José Antonio (2014). «A natural life: Neo-rurals and the power of everyday practices in protected areas». Journal of Political Ecology, 21 (1), 493-515. <http://dx.doi.org/10.2458/v21i1.21148>

D'Alisa, Giacomo et al. (2015). Decrecimiento, vocabulario para una nueva era. Barcelona: Icaria.

Fanjul, Sergio (2015). «De vuelta al campo». El País (5 de juny). Recuperat de <https://elpais.com/elpais/2015/06/05/ciencia/1433506840_516130.html>.

FERnÁndez, Oscar (2013). «Entre la evasión y la nostalgia: Estrategias de la neoruralidad desde la economía social». Gazeta de Antropología, 29 (2).

Folch, Rafel (2008). «Els moviments neorurals als Pirineus». Annals del Centre d'Estudis Comarcals del Ripollès, 385-398.

- (2011). «El movimiento neorrural en el Prepirineo de Lleida: El caso de la Terreta». A: Díaz, Luis; Fernández, Óscar i Tomé, Pedro (coords.). Lugares, tiempos, memorias: La antropología Ibérica en el siglo XXI. Lleó: Universidad de León, 2197-2206.

Global Ecovillage Network (2018). What is an ecovillage? Recuperat de <https:// ecovillage.org/projects/what-is-an-ecovillage/>.

Guirado, Carles (2012). Tornant a la muntanya: Migració, ruralitat $i$ canvi social al Pirineu Català. El cas del Pallars Sobirà. Tesi doctoral. Bellaterra: Universitat Autònoma de Barcelona.

HalfaCREE, Keith (2007). «Back-to-the-land in the twenty-first century - making connections with rurality». Tijdschrift voor Economische en Sociale Geografie, 98, 3-8. <https://doi.org/10.1111/j.1467-9663.2007.00371.x>

Hervieu, Bertrand i LÉGer, Daniel (1979). Le retour à la nature, au fond de la forêt... l'État. París: Le Seuil.

Hilmi, Angela i Burbi, Sara (2016). «Peasant Farming, a Refuge in Times of Crises». Development, 59, 3-4, 229-236. <https://doi.org/10.1057/s41301-017-0109-6>

Hong, Soonkwan i ViCDAN, Handan (2016). «Re-imagining the utopian: Transformation of a sustainable lifestyle in ecovillages». Journal of Business Research, 69 (1), 120-136. <https://doi.org/10.1016/j.jbusres.2015.07.026>

IBARgüEN, José Miguel (2004). «Neorrurales: Dificultades durante el proceso de asentamiento en el medio rural aragonés. Una visión a través de sus experiencias». CEDDAR Informes, 2004-3, $56 \mathrm{p}$.

Instituto Nacional de Estadística (2018). Padrón municipal de habitantes a 1 de enero de 2017. Recuperat de <www.ine.es>.

Kasper, D.V.S. (2008). "Redefining Community in the Ecovillage». Human Ecology Review, 15 (1), 13.

Larrañeta, Amaya (2016). "¿A vivir al campo?: Ahora más por deseo y con un proyecto de autoempleo que por necesidad». 20 Minutos (25 de maig). Recuperat de <http://www.20minutos.es/noticia/2755406/0/vivir-campo-neorurales-despoblacion-espana/\#xtor=AD-15\&xts=467263>.

Latouche, Serge (2007). Le pari de la décroissance. París: Fayard.

Laval, Christian i Dardot, P. (2015). Común. Barcelona: Gedisa.

Litfin, Karen T. (2014). Ecovillages: Lessons for Sustainable Community. Cambridge: Polity Press, 224 p.

Marconi, Valentina (2015). «Eco-villages in Catalonia: The rise of new green models in times of crisis». Catalan News (19 de juny). Recuperat de <http://www.catalan- 
news.com/life-style/item/eco-villages-in-catalonia-the-rise-of-new-green-modelsin-times-of-crisis $>$.

Menzies, Heather (2014). Reclaiming the Commons for the Common Good. Gabriola B. C.: New Societing Publishers.

Mingay, Gordon (ed.) (1989). The rural idyll. Londres: Routledge.

NoguÉ, Joan (1988). «El fenómeno neorrural». Agricultura y Sociedad, 47, 145-175.

Ostrom, Elinor (1990). Governing the commons: The evolution of institutions for collective action. Cambridge: Cambridge University Press.

Pallarès-Blanch, Marta; Prados, María José i Tulla, Antoni Francesc (2014). "Naturbanization and urban-rural dynamics in Spain: Case study of new rural landscapes in Andalusia and Catalonia». European Countryside, 2, 118-160. <https://doi.org/10.2478/euco-2014-0008>

Pickerill, Jenny (2016). "Building the commons in eco-communities». A: KIRWAN et al. (2016) (ed.). Space, power and the commons. Londres: Routledge.

- (2016). Eco-homes: People, place and politics. Londres: Zed Books.

Prados, María José (ed.) (2009). Naturbanization: New identities and processes for rural-natural areas. Leiden (Holanda): CPR Press.

Puebla, Pilar (2015). «Los repobladores de Sieso de Jaca claman por que se les reconozca dónde viven». El Heraldo de Aragón (6 de novembre de 2015). Recuperat de <https:/www.heraldo.es/noticias/aragon/2015/11/05/los_repobladores_sieso_ jaca_claman_por_que_les_reconozca_donde_viven_610303_300.html >.

Red IbÉRICA DE ECOALDEAs (2017). Ecovillages. Recuperat de <http://rie.ecovillage. org/inicio/>.

Resina, Joan Ramon i Viestenz, William (ed.) (2012). The New Ruralism: An Epistemology of Transformed Space. Madrid: Iberoamericana / Vervuert.

Romero, Luis del (2018). Despoblación y abandono de la España rural: El imposible vencido. València: Tirant lo Blanch.

Ruiz, Francisca (2008). «Nuevos escenarios en el mundo rural: Las comunidades alternativas». VIII Congreso SEAE. Bullas (Múrcia) 2008.

SEPE (2018). Publicado en el BOE el salario minimo interprofesional para 2018. Recuperat de <https:/www.sepe.es/HomeSepe/eu/que-es-el-sepe/comunicacion/noticias/historico-de-noticias/2018/detalle-noticia.html?folder=/2018/Enero/\&detail=smi_2018>.

Solana, Miguel (2008). "El encanto de lo rural, los términos del debate sobre la migración hacia áreas rurales desde la geografía británica y las contribuciones españolas: Un estado de la cuestión». Biblio 3w: Revista Bibliográfica de Geografía y Ciencias Sociales, XIII (776) (25 de febrer).

«Un pueblo abandonado a su suerte». El Faro del Guadarrama (31 de març de 2017). Recuperat de <http://www.elfarodelguadarrama.com/noticia/48787/el-reportaje/ navalquejigo:-un-pueblo-abandonado-a-su-suerte.html>.

Wilbur, Andrew (2013). «Growing a Radical Ruralism: Back-to-the-Land as Practice and Ideal». Geography Compass, 7, 149-160.

<https://doi.org/10.1111/gec3.12023>

Woods, Michael (2004). Rural geography. Los Angeles: SAGE.

Wright, Erik Olin (2010). Envisioning real utopias. Nova York: Verso. 


\section{Annex}

Entrevistes:

Les preguntes obertes principals de les entrevistes són les següents:

1. Pros i contres del model de vida a Matavenero.

2. Com cobreix les necessitats bàsiques d'aigua, subministrament d'energia, alimentació, habitatge i ocupació.

3. Relacions socials dins i fora de la comunitat.

Per voluntat expressa d'alguns entrevistats, en alguns casos no se n'ha inclòs el nom.

1. Minus, artesà, un dels primers pobladors de Matavenero.

2. Home entrevistat a Bembibre.

3. Artesana, una de les primeres pobladores de Matavenero.

4. Elgar Carpenter, estudiant, nascut a Matavenero.

Taula 2. Llista completa d'ecoviles amb dades bàsiques i informació primària sobre variables diverses

\begin{tabular}{|c|c|c|c|c|c|c|c|}
\hline Nom & Població & $\begin{array}{l}\text { Subministrament } \\
\text { d'aigua }\end{array}$ & $\begin{array}{l}\text { Subministrament } \\
\text { d'energia }\end{array}$ & Model d'alimentació & $\begin{array}{l}\text { Tècniques } \\
\text { de construcció }\end{array}$ & $\begin{array}{l}\text { Model de } \\
\text { propietat }\end{array}$ & $\begin{array}{l}\text { Model econòmic } \\
\text { i treball }\end{array}$ \\
\hline Aguinaliu & 17 & Aigua corrent & $\begin{array}{l}\text { Contracte amb empresa } \\
\text { subministradora }\end{array}$ & Producció pròpia & $\begin{array}{l}\text { Bioconstrucció, } \\
\text { intervencions } \\
\text { artístiques }\end{array}$ & Propietat privada & $\begin{array}{l}\text { Organització de tallers, } \\
\text { cursos i ecoturisme }\end{array}$ \\
\hline Argayali & 5 & Aigua corrent & Energia solar & Convencional & Materials moderns & Propietat privada & Allotjament \\
\hline Armejún & 4 & Fonts pròpies & Energia solar & $\begin{array}{l}\text { Sobirania alimentària } \\
\text { parcial }\end{array}$ & $\begin{array}{l}\text { Construcció amb } \\
\text { materials naturals }\end{array}$ & Okupació & Treballs convencionals \\
\hline Artiboirain & 150 & Fonts pròpies & Energia solar & $\begin{array}{l}\text { Sobirania alimentària } \\
\text { parcial }\end{array}$ & Bioconstrucció & Terres comunals & $\begin{array}{l}\text { Bioconstrucció i } \\
\text { organització de tallers }\end{array}$ \\
\hline Amayuelas & 20 & Aigua corrent & Renewable resources & $\begin{array}{l}\text { Ecologic cattle and } \\
\text { agriculture }\end{array}$ & $\begin{array}{l}\text { Construcció amb } \\
\text { materials naturals }\end{array}$ & Municipi ecològic & $\begin{array}{l}\text { Turisme rural, } \\
\text { organització de tallers } \\
\text { i agricultura }\end{array}$ \\
\hline Arterra & 60 & Aigua corrent & $\begin{array}{l}\text { Contracte amb } \\
\text { empresa } \\
\text { subministradora }\end{array}$ & $\begin{array}{l}\text { Ecologic cooperative, } \\
\text { own production }\end{array}$ & Tècniques modernes & Lloguer & $\begin{array}{l}\text { Cervesa, cosmètics, } \\
\text { turisme, aliments } \\
\text { orgànics... }\end{array}$ \\
\hline Beneficio & 300 & Fonts pròpies & Energia solar & $\begin{array}{l}\text { Ecològic i alt nivell de } \\
\text { sobirania alimentària }\end{array}$ & $\begin{array}{l}\text { Materials locals } \\
\text { i naturals }\end{array}$ & $\begin{array}{l}\text { Llibertat } \\
\text { d'assentament }\end{array}$ & $\begin{array}{l}\text { Sistemes de bescanvi, } \\
\text { agricultura, turisme... }\end{array}$ \\
\hline Calafou & 20 & Aigua corrent & Energia solar & $\begin{array}{l}\text { Sobirania alimentària } \\
\text { parcial }\end{array}$ & Materials moderns & Lloguer & $\begin{array}{l}\text { Cursos, sistemes } \\
\text { de bescanvi, } \\
\text { cooperativisme, recerca }\end{array}$ \\
\hline $\begin{array}{l}\text { Cortijo } \\
\text { Al Hammam }\end{array}$ & 10 & Fonts pròpies & Energia solar & $\begin{array}{l}\text { Ecològic i alt nivell de } \\
\text { sobirania alimentària }\end{array}$ & Materials moderns & Propietat privada & $\begin{array}{l}\text { Cursos de meditació } \\
\text { i ioga }\end{array}$ \\
\hline El Calabacino & 230 & Fonts pròpies & Energia solar & $\begin{array}{l}\text { Ecologic cattle and } \\
\text { agriculture }\end{array}$ & $\begin{array}{l}\text { Restauració amb } \\
\text { criteris ambientals }\end{array}$ & Propietat privada & $\begin{array}{l}\text { Turisme i activitats } \\
\text { culturals }\end{array}$ \\
\hline $\begin{array}{l}\text { El Valle } \\
\text { Despierta }\end{array}$ & 10 & Fonts pròpies & Energia solar & $\begin{array}{l}\text { Ecologic cattle and } \\
\text { agriculture }\end{array}$ & $\begin{array}{l}\text { Materials locals } \\
\text { i naturals }\end{array}$ & Propietat privada & Organització de tallers \\
\hline
\end{tabular}


Taula 2. Llista completa d'ecoviles amb dades bàsiques i informació primària sobre variables diverses (continuació)

\begin{tabular}{|c|c|c|c|c|c|c|c|}
\hline Nom & Població & $\begin{array}{l}\text { Subministrament } \\
\text { d'aigua }\end{array}$ & $\begin{array}{l}\text { Subministrament } \\
\text { d'energia }\end{array}$ & Model d'alimentació & $\begin{array}{l}\text { Tècniques } \\
\text { de construcció }\end{array}$ & $\begin{array}{l}\text { Model de } \\
\text { propietat }\end{array}$ & $\begin{array}{l}\text { Model econòmic } \\
\text { i treball }\end{array}$ \\
\hline Gaia Tasiri & 9 & Aigua corrent & $\begin{array}{l}\text { Contracte amb empresa } \\
\text { subministradora }\end{array}$ & $\begin{array}{l}\text { Ecològic i alt nivell de } \\
\text { sobirania alimentària }\end{array}$ & $\begin{array}{l}\text { Materials } \\
\text { moderns }\end{array}$ & Propietat privada & $\begin{array}{l}\text { Organització } \\
\text { de tallers }\end{array}$ \\
\hline Lakabe & 51 & Fonts pròpies & $\begin{array}{l}\text { Eòlica, hidràulica } \\
\text { i energia solar }\end{array}$ & $\begin{array}{l}\text { Ramaderia ecològica } \\
\text { i agricultura }\end{array}$ & $\begin{array}{l}\text { Materials locals } \\
\text { i naturals, biocons- } \\
\text { trucció }\end{array}$ & Okupació & $\begin{array}{l}\text { Activitats i treballs con- } \\
\text { vencionals i artesania }\end{array}$ \\
\hline Las Graceas & 3 & Fonts pròpies & Energia solar & Convencional & $\begin{array}{l}\text { Materials } \\
\text { moderns }\end{array}$ & Propietat privada & $\begin{array}{l}\text { Treballs } \\
\text { convencionals }\end{array}$ \\
\hline Los Portales & 30 & Aigua corrent & $\begin{array}{l}\text { Eòlica, hidràulica } \\
\text { i energia solar }\end{array}$ & $\begin{array}{l}\text { Ecològic i alt nivell de } \\
\text { sobirania alimentària }\end{array}$ & Bioconstrucció & Propietat privada & $\begin{array}{l}\text { Organització de tallers, } \\
\text { cursos i } \\
\text { seminaris }\end{array}$ \\
\hline Los Serpos & 5 & Fonts pròpies & Energia solar & Convencional & Bioconstrucció & Propietat privada & $\begin{array}{l}\text { Organització de } \\
\text { tallers i cursos }\end{array}$ \\
\hline Manzanares & 7 & Fonts pròpies & Energia solar & $\begin{array}{l}\text { Ecològic i alt nivell de } \\
\text { sobirania alimentària }\end{array}$ & $\begin{array}{l}\text { Restauració amb } \\
\text { materials naturals }\end{array}$ & Okupació & $\begin{array}{l}\text { Sistemes de } \\
\text { bescanvi, turisme }\end{array}$ \\
\hline Matavenero & 50 & Fonts pròpies & Energia solar & $\begin{array}{l}\text { Ecològic i alt nivell de } \\
\text { sobirania } \\
\text { alimentària }\end{array}$ & $\begin{array}{l}\text { Restauració amb } \\
\text { materials naturals } \\
\text { i moderns }\end{array}$ & Okupació & $\begin{array}{l}\text { Agricultura, } \\
\text { cosmètics, treballs } \\
\text { convencionals }\end{array}$ \\
\hline $\begin{array}{l}\text { Molino de } \\
\text { Guadalmesí }\end{array}$ & 8 & Fonts pròpies & Energia solar & $\begin{array}{l}\text { Ecològic i alt } \\
\text { nivell de sobirania } \\
\text { alimentària }\end{array}$ & Materials moderns & Propietat privada & $\begin{array}{l}\text { Organització de } \\
\text { tallers }\end{array}$ \\
\hline $\begin{array}{l}\text { Molino del } \\
\text { Río Aguas }\end{array}$ & 13 & Fonts pròpies & Energia solar & $\begin{array}{l}\text { Ecològic i alt } \\
\text { nivell de sobirania } \\
\text { alimentària }\end{array}$ & Bioconstrucció & Propietat privada & $\begin{array}{l}\text { Organització de } \\
\text { tallers i cursos }\end{array}$ \\
\hline Navalquejigo & 35 & Fonts pròpies & Energia solar & $\begin{array}{l}\text { Baix nivell de } \\
\text { sobirania alimentària }\end{array}$ & Bioclimàtic & Okupació & Treballs convencionals \\
\hline Navapalos & 10 & Fonts pròpies & Energia solar & $\begin{array}{l}\text { Baix nivell de } \\
\text { sobirania alimentària }\end{array}$ & Bioconstrucció & Propietat privada & Treballs convencionals \\
\hline Rala & 10 & Fonts pròpies & Energia solar & $\begin{array}{l}\text { Alt nivell de sobirania } \\
\text { alimentària }\end{array}$ & $\begin{array}{l}\text { Restauració amb } \\
\text { materials naturals } \\
\text { i moderns }\end{array}$ & Pública & Convencional \\
\hline Shakti & 8 & Aigua corrent & Energia solar & Convencional & Tècniques modernes & Propietat privada & Treballs convencionals \\
\hline Sieso de Jaca & 25 & Fonts pròpies & Fonts pròpies & $\begin{array}{l}\text { Baix nivell de } \\
\text { sobirania alimentària }\end{array}$ & Bioconstrucció & Okupació & $\begin{array}{l}\text { Voluntaris, sistemes de } \\
\text { bescanvi, organització } \\
\text { de tallers }\end{array}$ \\
\hline The Base & 10 & Aigua corrent & Energia solar & Convencional & $\begin{array}{l}\text { Materials naturals i } \\
\text { moderns }\end{array}$ & Propietat privada & $\begin{array}{l}\text { Organització de tallers } \\
\text { sobre bioconstrucció i } \\
\text { permacultura }\end{array}$ \\
\hline Uli Alto & 8 & Fonts pròpies & Energia solar & $\begin{array}{l}\text { Producció col·lectiva } \\
\text { i ramaderia }\end{array}$ & Materials moderns & Okupació & Agricultura i ramaderia \\
\hline Valdepiélagos & 100 & Aigua corrent & Energia solar & Convencional & Materials moderns & $\begin{array}{l}\text { Cooperativa d'ha- } \\
\text { bitatges }\end{array}$ & $\begin{array}{l}\text { Moneda social, sistemes } \\
\text { de bescanvi, teatre, } \\
\text { cosmètics }\end{array}$ \\
\hline $\begin{array}{l}\text { Valle de las } \\
\text { Sensaciones }\end{array}$ & 18 & Aigua corrent & Energia solar & $\begin{array}{l}\text { Ecològic i alt nivell de } \\
\text { sobirania alimentària }\end{array}$ & Bioconstrucció & Propietat privada & Organització de cursos \\
\hline
\end{tabular}

Font: elaboració pròpia a partir de contactes per correu i consultes de blogs, webs i xarxes socials de les ecoviles. 
